Bull. Iraq nat. Hist. Mus.

http://dx.doi.org/10.26842/binhm.7.2018.15.2.0189

December, (2018) 15 (2): 189-206

\title{
MINERALOGY AND GEOCHEMISTRY OF CORAL REEF IN IRAQI MARINE ENVIRONMENT IN THE NORTH PART OF ARABIAN GULF
}

\author{
Mohanad H. Al-Jaberi $^{*} \quad$ Moutaz A. Al-Dabbas ${ }^{* *} \quad$ Abather J. Bashar ${ }^{* * *}$ \\ and \\ Munaf Q. Jaber ${ }^{* * *}$ \\ * Department of Geology, College of Science, University of Basrah, Basrah, \\ Iraq \\ ** Department of Geology, College of Science, University of Baghdad, \\ Baghdad, Iraq \\ ${ }^{* * * *}$ Marine Science Center, University of Basrah, Basrah, Iraq \\ ${ }^{* *}$ Corresponding author: profaldabbas@yahoo.com
}

Received Date: 10 August 2018

Accepted Date: 19 November 2018

\begin{abstract}
Coral reef area in northwest of the Arabian Gulf was investigated for mineralogy and geochemistry to throw lights on such unique Iraqi Marine Environment; six specimens of two main species of coral reefs, Platygyra pini and Octocoral Menella were collected at two sites. While eight samples of the surrounding sediments are chosen from other two sites. The mineralogy is determined by XRD, and reveals that calcite, low magnesium-calcite, and aragonite are the main minerals that comprise the Octocoral Menella in site 1, whilst aragonite and calcite are dominate in the $P$. pini coral reef at site 4 .

The non-carbonate fractions indicate that these coral reefs contain quartz, anorthite feldspare, halite, and gypsum; the highest content of aragonite was observed in the $P$. pini compared to calcite. The abundance of carbonate minerals $(92.1 \%)$ in the $P$. pini is in contrast to $(73.1 \%)$ in the Menella. The main minerals in the sediments of site 2 are represented by chlorite and talc, whereas quartz and phengite are the most prominent minerals that diagnose in sediments of site 3; phengite mineral is a first discovery in the sediments of Arabian Gulf, whilst talc is a first detection in Iraqi marine sediments.

The concentration of $\mathrm{CaO}$ is the most abundant oxide in all the analyzed specimens of the coral reef followed by $\mathrm{SiO} 2$. There are high proportions of calcium oxide in $P$. pini Chevalier coral $(56.65 \%)$ than the Menella $(48.81 \%)$. There are some special pattern of distribution for major and trace elements in coral reef area based on calcium content. Most of the silica came from quartz, phengite and clay minerals; the highest concentrations of $\mathrm{Al}_{2} \mathrm{O}_{3}, \mathrm{Fe}_{2} \mathrm{O}_{3}, \mathrm{~K}_{2} \mathrm{O}$, $\mathrm{Na}_{2} \mathrm{O}, \mathrm{MgO}, \mathrm{SiO}_{2}, \mathrm{TiO}_{2}, \mathrm{~V}_{2} \mathrm{O}_{5}, \mathrm{Cr}, \mathrm{Ni}, \mathrm{Cu}, \mathrm{Rb}$ and $\mathrm{Zr}$ are found in the sediments of site 2 as opposed to the other sites. These results could affect the association of these elements with clay minerals through adsorption or absorption, the highest content of $\mathrm{P}_{2} \mathrm{O}_{5}, \mathrm{Ga}, \mathrm{W}$ and $\mathrm{As}$ in the sediments of site 3 may reflect the adsorption of these elements on surface of the quartz and phengite; from the other hand, the highest concentrations of $\mathrm{Sr}, \mathrm{Zn}, \mathrm{Br}, \mathrm{Sn}, \mathrm{Ta}$, and $\mathrm{Pb}$ in the $P$. pini may indicate the relative effects of the environmental variation within the studied area.
\end{abstract}

Keywords: Arabian Gulf, Coral Reefs, Iraq, Menella, Platygyra pini. 
Mineralogy and Geochemistry of Coral Reef in Iraqi Marine

\section{INTRODUCTION}

Coral reefs are among the greatest keys to unlock our understandings of a marine ecosystem (Perkol - Fenkel and Banayahu, 2007); this organism lives within exclusive temperature conditions and the sea water varieties survive between 14 to $34{ }^{\circ} \mathrm{C}$ (Coles and Fadlallah, 1991). Coral reefs of the Arabian Gulf and Oman Sea are serious habitats of cultural, socio-economic, and scientific importance. The seven countries surrounding the Arabian Gulf - Bahrain, Kuwait, Iran, Iraq, Qatar, Saudi Arabia and the United Arab Emirates - share a valuable ecosystem. Corals particularly in the Arabian Gulf are exposed to great summer sea temperatures compared with other tropical regions, with temperatures above $34^{\circ} \mathrm{C}$ for several months annually and summer maxima rising above $36^{\circ} \mathrm{C}$ (Coles and Riegl, 2013; Burt et al .,2015).

Salinity in the Arabian Gulf is also very high, generally between 35- 46 ppt in Iraqi marine environments (Al-Dabbas and Al-Jaberi, 2015), while in the shallow waters between Bahrain and Qatar, salinity often exceeds $50 \mathrm{ppt}$; these waters have the potential to offer important insights into how corals respond to temperature and salinity stress (Smith et al., 2017). Arabian Gulf reefs are relatively geographically isolated from the Indian Ocean by the narrow (42 km wide) Strait of Hormuz, yet are relatively young current shorelines (reached $\sim 6000$ years ago) (Lambeck, 1996); however it is unclear whether there has been enough isolation to support genetic adaptation to the local environment. Around the world, reefs grow at temperatures of about $28^{\circ} \mathrm{C}$ and above a certain threshold, the corals start expelling the algae from their tissue in a phenomenon known as coral bleaching. Bleached corals can sometimes recover, but, in many cases, die. In Australia, corals start to bleach if the water reaches $31^{\circ} \mathrm{C}$. However, in the Arabian Gulf, bleaching starts at 35 to $36^{\circ} \mathrm{C}$. In most areas of the Arabian Gulf, corals do not form true reefs, but are better described as 'coral carpets', where separate colonies a raise on exposed rocky substrates rather than building on older dead coral skeletons (Burt et al.,2015).

Seasonal changes in the intimate environment of coral reefs cause a physiological effect on these organisms ( Eghtesadi- Araghi, 2011); Arabian Gulf coral groups are on average, smaller in size relative to their counterparts living in more benign conditions outside the area (Burt, 2013); the lack of larger sized colonies within the Arabian Gulf indicates that most individual colonies may not survive for the lengths of time they do in areas outside of the Gulf, as a result of the harsh nature of the Gulf environment (Riegl and Purkis, 2012).

The Arabian Gulf coral reef communities can be classified according to place of growth in the water, (a) offshore deep water reefs and (b) near shore shallow water reefs Burt et al. (2015) distinguishes two types of coral reef communities in Qatar, shallow communities (600 $\mathrm{m}$ from the shore) at a depth of $3 \mathrm{~m}$, and deep communities (40 km from the shore) at a depth of $25 \mathrm{~m}$. Pilcher et al. (2000) refers to the depth of near shore coral reefs in Kuwait as ranging between 10 to $15 \mathrm{~m}$, while the offshore coral reefs are surrounded by a $30 \mathrm{~m}$ depth.

Rezai and Savari (2004) asserts that coral cover in the Gulf of Oman is typically 30-40\% at depths of 4-12 m; the only significant population of living coral in Bahrain is surrounded by $40 \mathrm{~m}$ deep sea water; comparatively coral reef communities in offshore and near- shore in Iran range at 3 to $15 \mathrm{~m}$ (Rezai and Savari, 2004). Total coral reef area coverage in the UAE which occurs primarily as shoals and which localises around the numerous offshore islands, ranges at less than $20 \mathrm{~m}$ deep (Riegl, 2002). Most coral reefs communities in the Arabian Gulf are near-shore shallow water reefs; coral reefs use calcium carbonate $\left(\mathrm{CaCO}_{3}\right)$ from sea water 
Al-Jaberi et al.

to synthesize a hard and protective marine shells (Kleypas et al.,1999; Langdon et al., 2000; Falter et al., 2001).

In the ocean, where aragonite saturation decreases, the effect will tend to favor organisms that create the more stable forms of calcium carbonate, such as calcite and high magnesium calcite; aragonite-creating organisms, like corals, will in turn be subject to more dissolution and bio-erosion, calcification of all groups, however; is negatively affected by the decrease in the carbonate saturation of sea waters (Feely et al., 2004). Coral reefs in the northern and northwestern territories of the Arabian Gulf are exposed to a very heavy load of particles that derive their input from the Shatt Al-Arab River of Iraq; nine species of coral reefs we are discovered in the Iraqi marine environment between September of 2012 and May of 2013 by Marine Science Center (MSC) of Basrah, Iraq and Scientific Diving Center (SDC) of Freiberg, Germany (Pohl et al.,2014).

This investigation aims to describe the mineralogy and geochemistry of Iraqi coral reefs and the surrounding marine sediments.

\section{MATERIALS AND METHODS}

Iraqi coral reefs are offshore, distributed within a space of approximately $28 \mathrm{~km}^{2}$, at depths ranging between 7-20 $\mathrm{m}$ (Pohl et al., 2014) (Map 1). The study area is located in the northwest Arabian Gulf between $29^{\circ} 36^{\prime} 30^{\prime} \mathrm{N}-29^{\circ} 39^{\prime} 20.94^{\prime \prime} \mathrm{N}$ latitude and $48^{\circ} 48^{\prime} 21.2^{\prime \prime} \mathrm{E}$ $48^{\circ} 49^{\prime} 89.1^{\prime \prime} \mathrm{E}$ longitude (Map 2, Tab. 1). This investigation aims to describe the mineralogy and geochemistry of Iraqi coral reefs and the surrounding marine sediments.

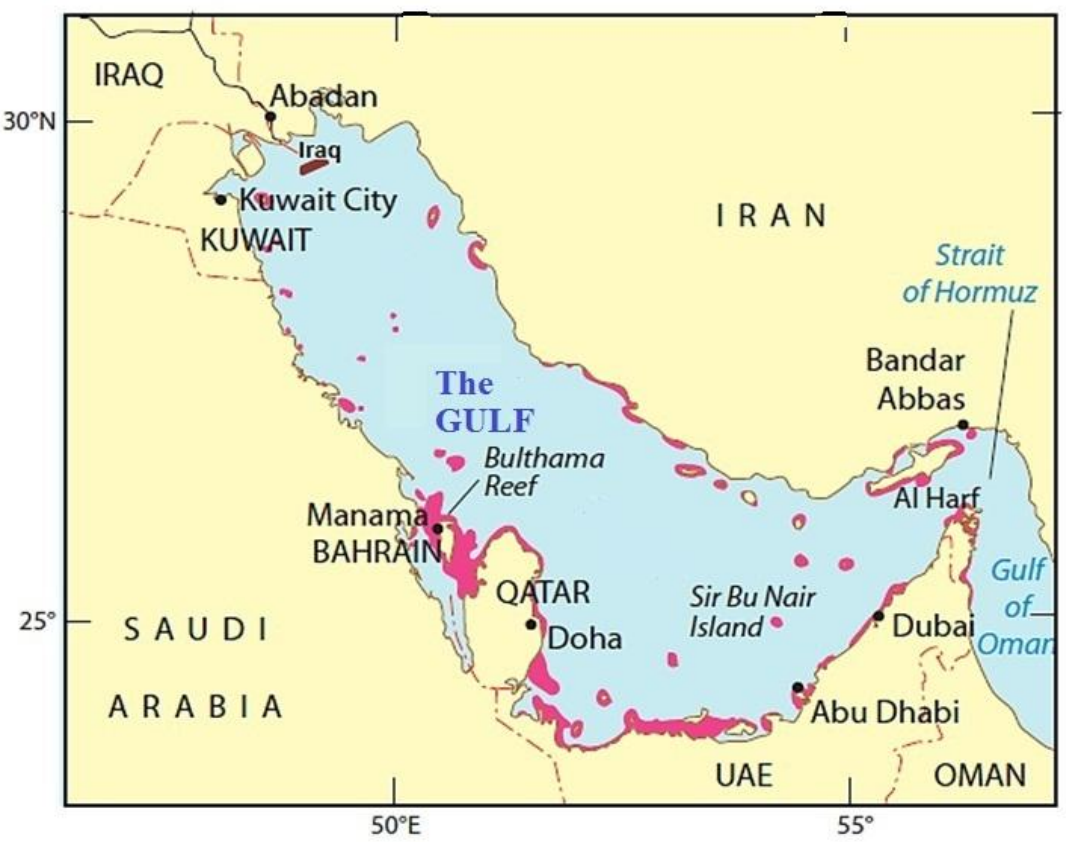

Map (1): Modified map of coral reefs distribution according to Burt et al. (2015), with illustrating the Iraqi coral reefs 
Mineralogy and Geochemistry of Coral Reef in Iraqi Marine

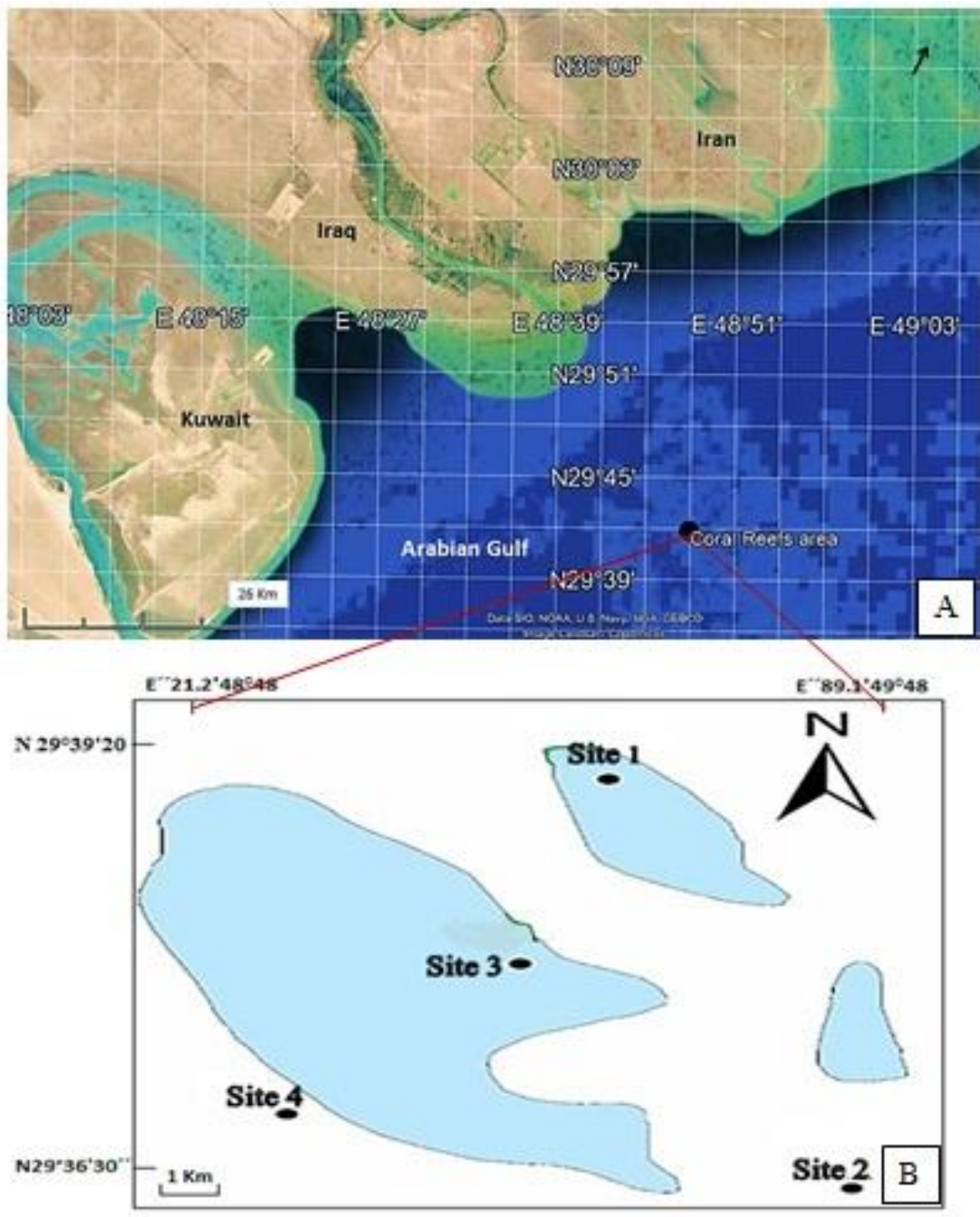

Map (2): (A) Regional map of the coral reefs area, (B) magnified map of the coral reef area illustrating the position of research Sites.

Table (1): Site coordinates of the study area

\begin{tabular}{|c|lc|}
\hline Site & \multicolumn{2}{|c|}{ Coordinates } \\
\hline 1 & $29^{\circ} 39^{\prime} 20.94^{\prime \prime} \mathrm{N}$ & $48^{\circ} 49^{\prime} 30.6^{\prime} \mathrm{E}$ \\
\hline 2 & $29^{\circ} 36^{\prime} 30^{\prime \prime} \mathrm{N}$ & $48^{\circ} 49^{\prime} 89.1^{\prime \prime} \mathrm{E}$ \\
\hline 3 & $29^{\circ} 38^{\prime} 02.8^{\prime} \mathrm{N}$ & $48^{\circ} 49^{\prime} 12.4^{\prime \prime} \mathrm{E}$ \\
\hline 4 & $29^{\circ} 36^{\prime} 59.0^{\prime} \mathrm{N}$ & $48^{\circ} 48^{\prime} 21.2^{\prime} \mathrm{E}$ \\
\hline
\end{tabular}




\section{Al-Jaberi et al.}

Fourteen specimens from coral reefs and marine sediments are selected in four sites in the Iraqi coral reefs area; all the specimens were collected by experienced scientific divers from MSC in University of Basrah. Six from them represent deferent two species of coral reefs. Three specimens collected from the Menella species and another three from $P$. pini (Sites 1 and 4). Eight specimens are collected from the surrounding marine sediments in the coral reefs area (Sites 2 and 3), four specimens from site 2, and four from site 3 as shown in Map (2 b); specimens were taken in plastic boxes and transported to the geology laboratory in Basrah University.

Mineral identification of the specimens took place with X-ray diffraction patterns obtained by means of a $\mathrm{D}-5000 \mathrm{X}$-ray diffractometer, using $\mathrm{CuK} \alpha$ sources in wavelength, $\mathrm{v}$ being $1.54056 \AA$ at $40 \mathrm{kV}$ and $30 \mathrm{~mA}$ between $5-65^{\circ}$. Geochemical analyses for the major and trace elements were calculated by Inductively Coupled Plasma - Atomic Emission Spectrometry (ICP-AES) method for major oxides $\left(\mathrm{Al}_{2} \mathrm{O}_{3}, \mathrm{SiO}_{2}, \mathrm{CaO}, \mathrm{MgO}, \mathrm{Fe}_{2} \mathrm{O}_{3}, \mathrm{Na}_{2} \mathrm{O}, \mathrm{K}_{2} \mathrm{O}, \mathrm{P}_{2} \mathrm{O}_{5}\right.$, $\mathrm{TiO}_{2}, \mathrm{~V}_{2} \mathrm{O} 5, \mathrm{MnO}$, and $\mathrm{SrO}$ ), and Inductively Coupled Plasma - Mass Spectrometry (ICPMS) method for trace elements (Ni, Cu, Zn, As, Ga, Br, Rb, Zr, Mo, Sn, Ta, W, Pb, and Cr) at the ALS Laboratories in Spain.

\section{(A) Mineralogical Analysis}

\section{RESULTS AND DISCUSSION}

Coral contains the carbonate minerals from the coral skeleton, but also contains many minerals that are a natural chelate due to the zooxanthellae that grows on the coral (Devnita, 2009); calcite, aragonite and dolomite create more than $90 \%$ of carbonate minerals of coral reefs (Scherer, 1986). They form as grains and cements in the body of corals (Tucker and Hollingworth, 1986); besides those minerals, there are also other minerals, which build coral reefs as minor components (Schroeder and Purser, 1986), the mineralogical composition of sediments around coral reefs is derived from the reef itself (Devnita, 2009); the composition of the specimens in the studied sites has been recognized by X-ray diffraction analyses.

The bulk mineral components and the relative abundance of each mineral have been considered on the basis of peak high measurements of a $100 \%$ reflection peak; the data attained are summarized in Table (2) and selected X-ray diffractograms are provided in Diagrams (1, 2, 3, and 4); carbonate minerals obtained in the Menella sp.l (Site 1) are calcite, low Mg-calcite, and aragonite. Calcite recorded here dominates over aragonite; the non carbonate fractions show that the Menella contain quartz, anorthite feldspar, and halite. However, these minerals are not the dominant minerals normally found in these reefs (Tab. 2)

Aragonite and calcite could be the main carbonate minerals of the $P$. pini in site 4 , it formed more than $92 \%$ from the total minerals of this reef, and recorded here dominates over calcite, quartz and halite are recorded at lower constituents regarding this species of coral reef. The abundance of carbonate minerals $(92.1 \%)$ in the species of $P$. pini is in contrast to volumes present in the Octocoral Menella species (73.1\%). The content of carbonate minerals in Iraqi coral reefs are seemingly higher than the adjacent coral reefs in Kuwait and Saudi Arabia (Al-Langawi, 2013; Basyoni,1999). Non-carbonate minerals attributed to these corals may indicate that rock fragments within the coral reef area stems not only from the origin of the reef, but also from other sources, since feldspar and quartz arise from igneous rocks. Major minerals in the sediments of site 3 are quartz, phengite, and gypsum. The clay minerals, chlorite and talc comprise more than $96 \%$ of the total minerals in the sediments of site 2 (Tab. 2). The Phengite is the first recorded mineral in sediments of the Arabian Gulf, while talc has been the first detected in Iraqi marine sediments. Phengite is similar to muscovite, 


\section{Mineralogy and Geochemistry of Coral Reef in Iraqi Marine}

but with the addition of magnesium, iron and an overall high silica content (Mookherjee and Redfern, 2002).

Cibin et al. (2008) proposes that phengite is an aluminum true mica which contains a high amount of tetrahedral co-ordinated silica; most of the phengite have a fluorine content that uses an indicator for metamorphosed sediments (liu et al., 2009). Talc is a hydrous silicate composed of magnesium, silica and water that is relatively pure in composition, but can contain small amounts of aluminum, iron, manganese and titanium; it ore from within the deposit originates from hydrothermal alteration processes involving of magnesium minerals, mainly olivine and orthopyroxenes, but may also occur from a process of regional metamorphism or contact with magnesium calcareous or ultrabasic rocks (Pontes and Almeida, 2005). This occurrence is associated with a mineral presence of biotite, chlorite, serpentine and carbonates (Machado, 2016). In subduction zone metamorphism that leads to continuous reduction of water stored, hydrous minerals in metapelites are evident as potassic mica (phengite), whereas other important hydrous phases in subdution zones are talc and chlorite as shown by Schmidt and Poli (2014).

Chen et al. (2017) mentioned the phengite is a critical carrier of water and potassium (K) in sediment as well as in the basaltic layers of subducted slabs; the data herein provides sufficient conclusions that the source of discovering the phengite, talc and chlorite in the sediments of coral reefs in the study area may be derived from metamorphic rocks that formed during subduction processes between Arabian and Persian plates.

Table (2): Minerals are recognized within the research sites

\begin{tabular}{|c|c|c|c|}
\hline Sites & Mineral & Chemical Formula & $\begin{array}{c}\text { Percentage } \\
\%\end{array}$ \\
\hline \multirow{6}{*}{ Site 1} & Calcite & $\mathrm{CaCO}_{3}$ & 31.8 \\
\hline & Mg-Calcite & $\mathrm{Ca}_{0.9} \mathrm{Mg}_{0.1} \mathrm{CO}_{3}$ & 20.7 \\
\hline & Aragonite & $\mathrm{CaCO}_{3}$ & 20.6 \\
\hline & Quartz & $\mathrm{SiO}_{2}$ & 16.6 \\
\hline & $\begin{array}{l}\text { Anorthite } \\
\text { feldspar }\end{array}$ & $\mathrm{Al}_{2} \mathrm{Ca}_{0.2} \mathrm{O}_{8} \mathrm{Si}_{2} \mathrm{Sr}_{0.8}$ & 7.3 \\
\hline & Halite & $\mathrm{NaCl}$ & 3 \\
\hline \multirow{3}{*}{ Site 2} & Chlorite & $\mathrm{Al}_{0.865} \mathrm{Fe}_{0.255} \mathrm{H}_{4} \mathrm{Mg}_{2 \cdot 292} \mathrm{O}_{9} \mathrm{Si}_{1.588}$ & 80 \\
\hline & Talc & $\mathrm{H}_{2} \mathrm{Mg}_{3} \mathrm{O}_{12} \mathrm{Si}_{4}$ & 16.5 \\
\hline & Gypsum & $\mathrm{CaH}_{4} \mathrm{O}_{6} \mathrm{~S}$ & 3.5 \\
\hline \multirow{3}{*}{ Site 3} & Quartz & $\mathrm{SiO} 2$ & 57.5 \\
\hline & Phengite & $\mathrm{Al}_{9.12} \mathrm{Fe}_{1.12} \mathrm{~F}_{0.16} \mathrm{H}_{8} \mathrm{~K}_{2} \mathrm{MgNa}_{0.1} \mathrm{O}_{48} \mathrm{Si}_{13}$ & 35 \\
\hline & Gypsum & $\mathrm{CaH} 4 \mathrm{O} 6 \mathrm{~S}$ & 7.5 \\
\hline \multirow{4}{*}{ Site 4} & Aragonite & $\mathrm{CaCO}_{3}$ & 63.8 \\
\hline & Calcite & $\mathrm{CaCO}_{3}$ & 28.3 \\
\hline & Quartz & $\mathrm{SiO}_{2}$ & 5 \\
\hline & Halite & $\mathrm{NaCl}$ & 2.9 \\
\hline
\end{tabular}


Al-Jaberi et al.

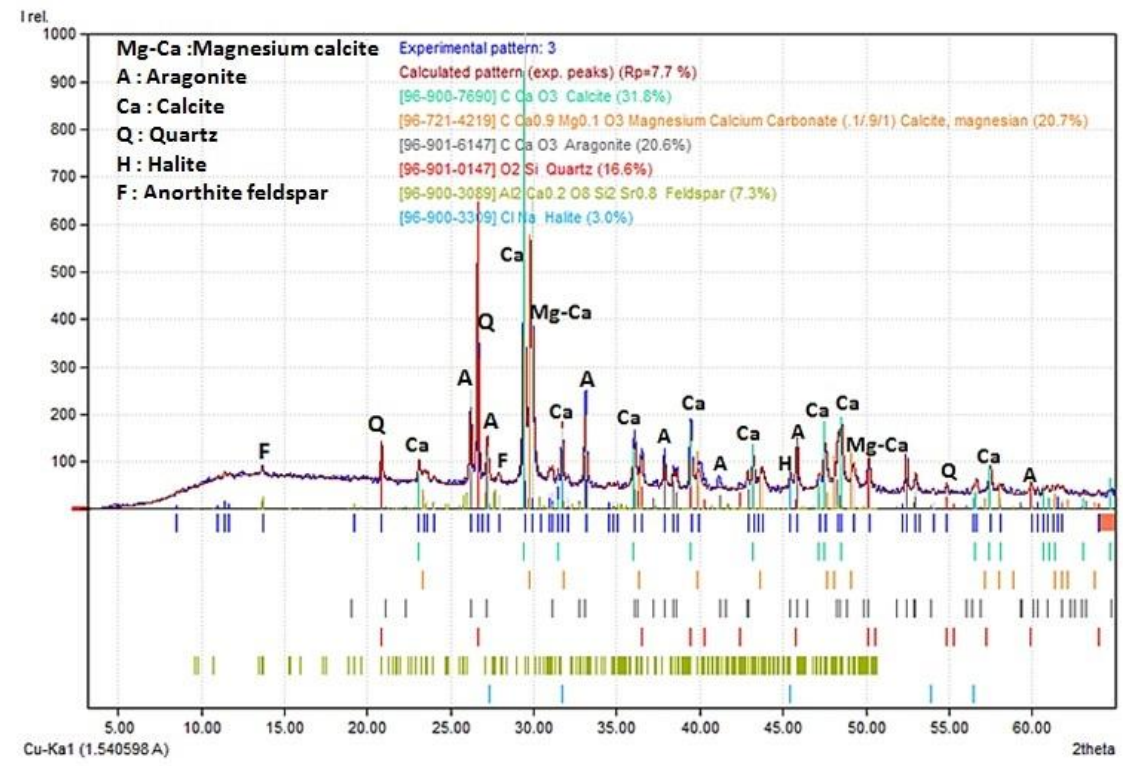

Diagram (1): XRD of Octocoral Menella coral reef in Site 1.

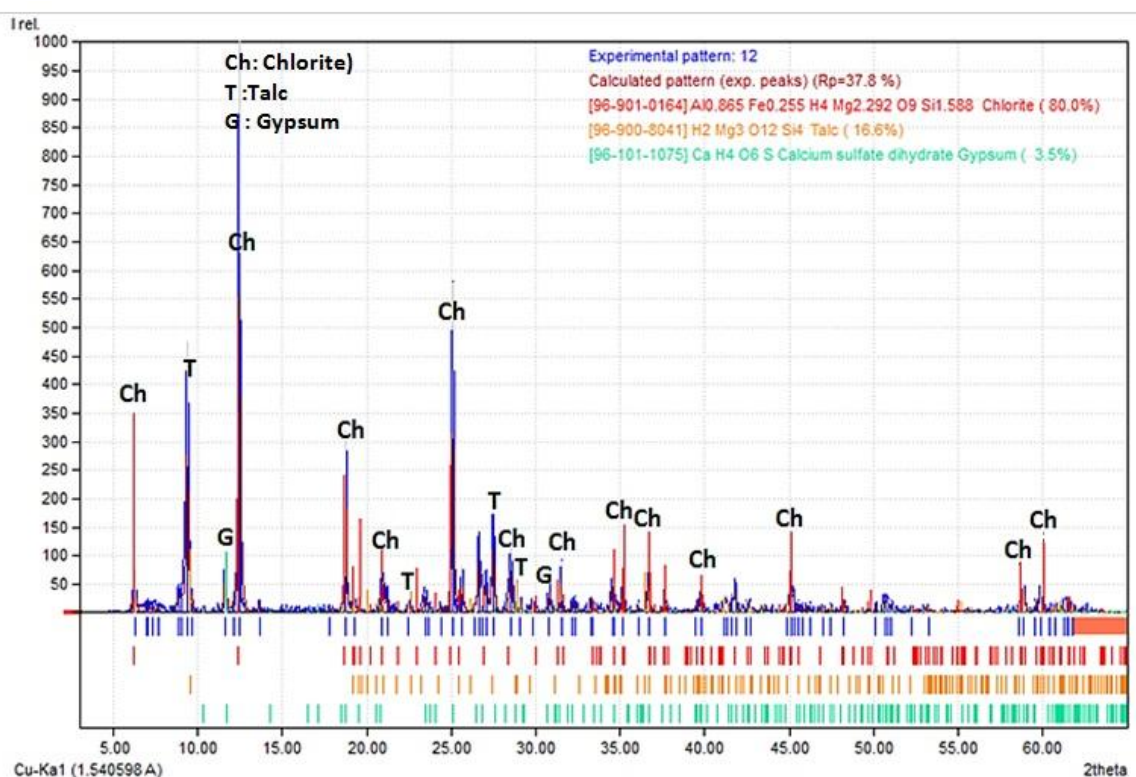

Diagram (2): XRD of marine sediments in Site 2. 
Mineralogy and Geochemistry of Coral Reef in Iraqi Marine

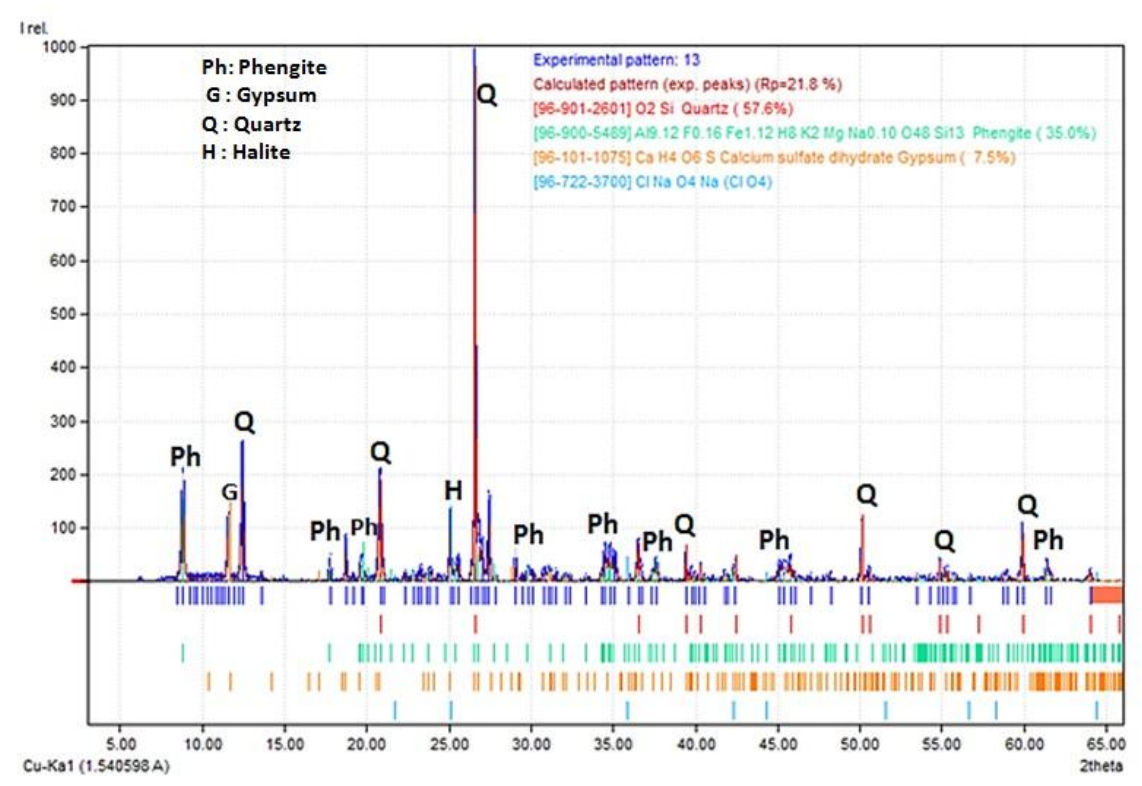

Diagram (3): XRD of marine sediments in Site 3.

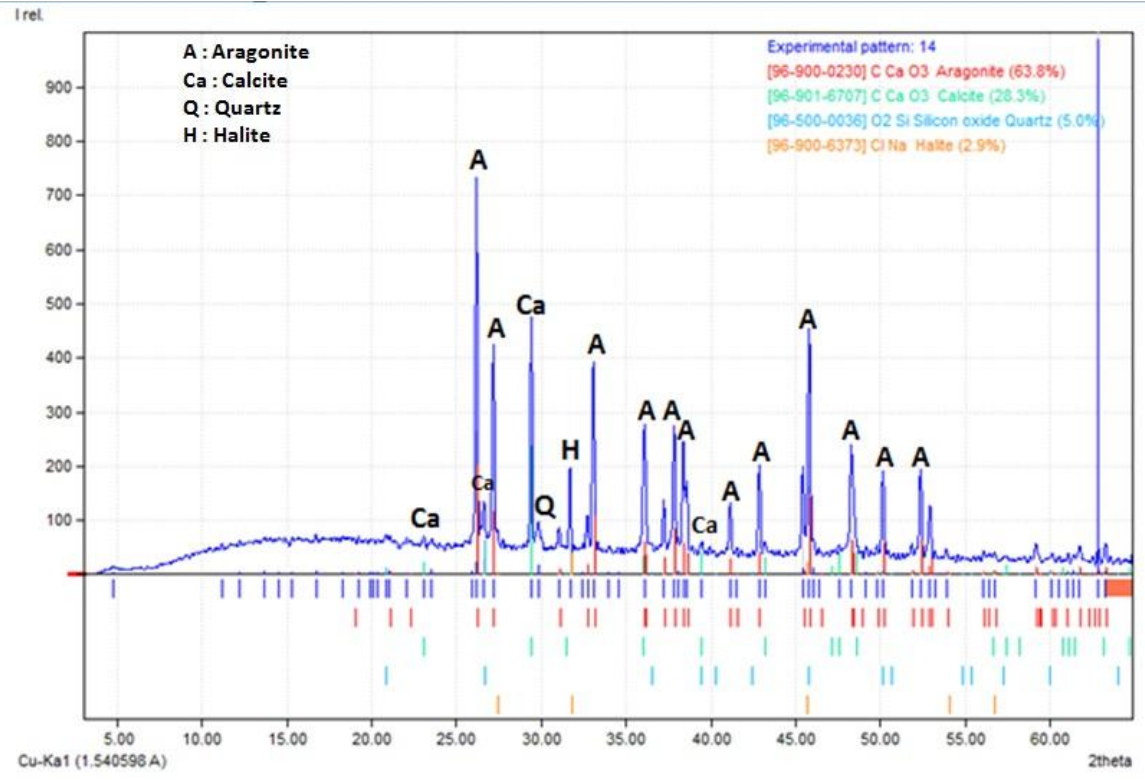

Diagram (4): XRD of Platygyra pini coral reef in Site 4 
Al-Jaberi et al.

\section{(B) Geochemical Analysis}

The mineralogical composition of coral reefs depends upon the organisms which composed them (Schroeder and Purser, 1986); coral reefs which are built by carbonate sedimentary rocks are comprised more than $50 \%$ of carbonate minerals and these minerals contain $\mathrm{CO}_{3}{ }^{2-}$ with one or more cations of calcium, magnesium and also iron (Kerans et al., 1986). Elements distribution in marine sediments reflects the range of chemical, oceanographic, and sedimentary controls on their supply to their distribution (Clavert and Pederson, 1993).

The concentration of the major oxides $\left(\mathrm{Al}_{2} \mathrm{O}_{3}, \mathrm{SiO}_{2}, \mathrm{CaO}, \mathrm{MgO}, \mathrm{Fe}_{2} \mathrm{O}_{3}, \mathrm{Na}_{2} \mathrm{O}, \mathrm{K}_{2} \mathrm{O}, \mathrm{P}_{2} \mathrm{O}_{5}\right.$, $\mathrm{TiO}_{2}, \mathrm{~V}_{2} \mathrm{O} 5, \mathrm{MnO}$, and $\mathrm{SrO}$ ) and trace elements (Ni, $\mathrm{Cu}, \mathrm{Zn}, \mathrm{As}, \mathrm{Ga}, \mathrm{Br}, \mathrm{Rb}, \mathrm{Zr}$, Mo, Sn, Ta, $\mathrm{W}, \mathrm{Pb}$, and $\mathrm{Cr}$ ) have been measured in the collected samples, and its data are presented in Tables ( 3 and 4); the purpose of chemical analysis of the coral reef area is to identify the chemical variations in coral composition and surrounding marine sediments, calcium oxide is the most abundant oxide in all of the analyzed coral reef area followed by silica oxide. At site 4 reefs were found to contain higher proportions of calcium oxide in the P. pini $(56.65 \%)$ than the Octocoral Menella coral species $(48.81 \%)$ at site 3, that actually confirmed the mineralogy study as mentioned in Table 2 . The interesting in the geochemical analysis of marine sediments in coral reef area is the larger percentages of calcium oxide than the other calcium contents in Iraqi marine sediments; Al-Jaberi (2015) gave important information about the content of major and trace elements in Iraqi marine sediments; stated that calcium oxide range in these sediments between 13.1-23\%. Whilst, the content of calcium oxide in the sediments of study area ranges between $35.22-39.61 \%$ as shown in Table (3), which reflect the important role of coral reefs to provide the marine sediments at the studied area by carbonate minerals. However, there were some special pattern of distribution for major and trace elements in coral reef areas based on $\mathrm{CaO}$ content; the distribution of major oxides and trace elements are listed in Diagrams $(5,6,7,8,9,10) ; \mathrm{CaO}$ is increase in studying sites with decrease $\mathrm{SiO}_{2}$ (Diag. 5), which indicates that silica oxides, mostly come from non- carbonate minerals represented by quartz, phengite and clay minerals in the sediments of the coral reef area. Also, the relation between $\mathrm{CaO}$ and $\mathrm{MgO}$ is belong to this group as well (Diag. 5,6).

Basyoni (1999) mentioned that the negative correlation between $\mathrm{CaO}$ and $\mathrm{MgO}$ in coral reefs may be attributed to acid soluble carbonate $\left(\mathrm{CaCO}_{3}\right)$ fractions and the mineralogical composition of the sediments; the largest values of major constituents: $\mathrm{SiO}_{2}, \mathrm{Al}_{2} \mathrm{O}_{3}, \mathrm{MgO}$, $\mathrm{Fe}_{2} \mathrm{O}_{3}, \mathrm{~K}_{2} \mathrm{O}, \mathrm{Na}_{2} \mathrm{O}, \mathrm{TiO}_{2}, \mathrm{~V}_{2} \mathrm{O}_{5}$ and $\mathrm{MnO}$, and trace elements $(\mathrm{Ni}, \mathrm{Cu}, \mathrm{Cr}, \mathrm{Rb}$, and $\mathrm{Zr}$ ) associated with clay minerals (chlorite and talc) are evident at site 2 as shown in Diagrams (5, $6,7,8,9,10)$. On the other hand, the content of $\mathrm{CaO}$ in this site is the lowest compared with the other sites; these results can be explained by the presence of these elements in the noncarbonate constituents of clay minerals. Alumina and silica in the sediments of this site can be considered as main constituents in the chemical composition of clay minerals; physiochemical exploration of marine sediments may provide a vision of a possible mechanism of trace elements accompanied with clay minerals, revealing adsorption on the surface or inclusion in the crystal lattice (Kahn et al., 1992).

In the site 3 , sediments were found to contain a high proportion of silica oxide (20.25\%), and most of this oxide may relate to the content of quartz and phengite minerals. The highest $\mathrm{P}_{2} \mathrm{O}_{5}, \mathrm{Ga}, \mathrm{W}$, and As concentrations were also encountered in this site ( Diag. 7, 8, 9), as a result of their adsorption on the surface of the quartz and phengite. The content of the SrO in P. pini was higher than the Menella sp. (Tab. 3, Diag. 6). Bathurst (1975) emphasized that the aragonite and calcite can hold some strontium level. The free energy of mixing of the strontium $\mathrm{Sr}^{2+}$ in the aragonite is greater than in the calcite, thus preferring the aragonite 
Mineralogy and Geochemistry of Coral Reef in Iraqi Marine

(Basyoni , 1999); Deer et al. (1992) states that a major control on trace and minor elements in either calcite or aragonite is crystallochemical .

The calcite structure accommodates $\mathrm{Ca}^{2}$ (ionic radius $1.00 \AA$ ) as well as minor and trace elements having an ionic radius less than or equal to $1.00 \AA$, the aragonite structure accommodates $\mathrm{Ca}^{2}$ together with minor and trace elements having radii close to or greater than $1.00 \AA$; Al-Dabbas and Al-Jaberi (2015) confirm that elements which have ionic radii close to or more than $1 \AA$ are visible at higher concentrations in aragonite than in the calcite layer. This conclusion may probably enhance the results in Table (3), which can be used to explain the highest content of $\mathrm{Sr}, \mathrm{Zn}, \mathrm{Br}, \mathrm{Pb}, \mathrm{Ta}$, and $\mathrm{Sn}$ in the $P$. pini at site 4 compare to others; these elements have obvious positive relationships with calcium oxide as shown in Diagrams $(6,8,9,10)$. While, a high content of Mo with Octocoral Menella coral reef ( Diag. $10)$ is reflect the presence of this element in calcite layer.

Table (3):Range and mean values of major oxides in studied sites.

\begin{tabular}{|c|c|c|c|c|c|c|c|c|}
\hline \multirow{2}{*}{$\begin{array}{c}\text { Element } \\
\%\end{array}$} & \multicolumn{2}{|c|}{ Site 1} & \multicolumn{2}{|c|}{ Site 2} & \multicolumn{2}{|c|}{ Site 3} & \multicolumn{2}{|c|}{ Site 4} \\
\hline & Range & Mean & Range & Mean & Range & Mean & Range & Mean \\
\hline $\mathrm{Al}_{2} \mathrm{O}_{3}$ & $\begin{array}{l}1.125- \\
2.0\end{array}$ & 1.56 & $3.08-3.12$ & 3.1 & $\begin{array}{l}2.027- \\
2.05 \\
\end{array}$ & 2.03 & $\begin{array}{l}0.348- \\
0.35 \\
\end{array}$ & 0.349 \\
\hline $\mathrm{SiO}_{2}$ & $\begin{array}{l}10.43- \\
10.56 \\
\end{array}$ & 10.45 & $\begin{array}{l}24.32- \\
24.5 \\
\end{array}$ & 24.41 & $\begin{array}{l}20.25- \\
20.32 \\
\end{array}$ & 20.28 & $2.75-2.81$ & 2.78 \\
\hline $\mathrm{CaO}$ & $\begin{array}{l}48.81- \\
49.12 \\
\end{array}$ & 48.96 & $\begin{array}{l}35.22- \\
35.27 \\
\end{array}$ & 35.24 & $\begin{array}{l}39.41- \\
39.61\end{array}$ & 39.51 & $\begin{array}{l}56.65- \\
56.67\end{array}$ & 56.66 \\
\hline $\mathrm{MgO}$ & $2.0-2.2$ & 2.1 & $2.82-2.9$ & 2.86 & $2.41-2.5$ & 2.455 & $0.74-0.79$ & 0.76 \\
\hline $\mathrm{Fe}_{2} \mathrm{O}_{3}$ & $\begin{array}{l}1.242- \\
1.25\end{array}$ & 1.24 & $\begin{array}{l}1.989- \\
1.99\end{array}$ & 1.989 & $\begin{array}{l}1.608- \\
1.62 \\
\end{array}$ & 1.61 & $\begin{array}{l}0.259- \\
0.27\end{array}$ & 0.26 \\
\hline $\mathrm{Na}_{2} \mathrm{O}$ & $\begin{array}{l}1.96- \\
2.1\end{array}$ & 2.03 & $3.82-3.86$ & 3.84 & $1.77-1.8$ & 1.78 & $\begin{array}{l}2.413- \\
2.43\end{array}$ & 2.42 \\
\hline $\mathrm{K}_{2} \mathrm{O}$ & $\begin{array}{l}0.239- \\
0.242 \\
\end{array}$ & 0.24 & $\begin{array}{l}0.644- \\
0.67 \\
\end{array}$ & 0.667 & $\begin{array}{l}0.409- \\
0.42 \\
\end{array}$ & 0.41 & $\begin{array}{l}0.073- \\
0.075 \\
\end{array}$ & 0.074 \\
\hline $\mathrm{P}_{2} \mathrm{O}_{5}$ & $\begin{array}{l}0.104- \\
0.106 \\
\end{array}$ & 0.105 & $\begin{array}{l}0.1007- \\
0.1009 \\
\end{array}$ & 0.1008 & $\begin{array}{l}0.142- \\
0.15 \\
\end{array}$ & 0.146 & $\begin{array}{l}0.044- \\
0.05 \\
\end{array}$ & 0.047 \\
\hline $\mathrm{TiO}_{2}$ & $\begin{array}{l}0.127- \\
0.13 \\
\end{array}$ & 0.128 & $\begin{array}{l}0.266- \\
0.27 \\
\end{array}$ & 0.26 & $\begin{array}{l}0.179- \\
0.21 \\
\end{array}$ & 0.194 & $\begin{array}{l}0.034- \\
0.042 \\
\end{array}$ & 0.038 \\
\hline $\mathrm{V}_{2} \mathrm{O}_{5}$ & $\begin{array}{l}0.0043- \\
0.0047\end{array}$ & 0.0045 & $\begin{array}{l}0.0095- \\
0.0098\end{array}$ & 0.0096 & $\begin{array}{l}0.0074- \\
0.0082\end{array}$ & 0.0078 & $\begin{array}{l}0.0067- \\
0.0072\end{array}$ & 0.0069 \\
\hline $\mathrm{MnO}$ & $\begin{array}{l}0.0294- \\
0.03\end{array}$ & 0.0297 & $\begin{array}{l}0.056- \\
0.058 \\
\end{array}$ & 0.057 & $\begin{array}{l}0.0399- \\
0.043\end{array}$ & 0.041 & $\begin{array}{l}0.00636- \\
0.0068\end{array}$ & 0.0065 \\
\hline $\mathrm{SrO}$ & $\begin{array}{l}0.233- \\
0.25\end{array}$ & 0.241 & $\begin{array}{l}0.077- \\
0.079\end{array}$ & 0.078 & $\begin{array}{l}0.0968- \\
0.098\end{array}$ & 0.097 & $\begin{array}{l}0.841- \\
0.871\end{array}$ & 0.865 \\
\hline L.O.I & $\begin{array}{l}33.5- \\
33.54\end{array}$ & 33.52 & $\begin{array}{l}27.39- \\
27.44\end{array}$ & 27.41 & $\begin{array}{l}31.46- \\
31.52\end{array}$ & 31.49 & $\begin{array}{l}35.73- \\
35.82\end{array}$ & 35.77 \\
\hline
\end{tabular}


Al-Jaberi et al.

Table (4): Range and mean values of trace elements in studied sites.

\begin{tabular}{|c|c|c|c|c|c|c|c|c|}
\hline \multirow{2}{*}{$\begin{array}{l}\text { Element } \\
\text { ppm }\end{array}$} & \multicolumn{2}{|c|}{ Site 1} & \multicolumn{2}{|c|}{ Site 2} & \multicolumn{2}{|c|}{ Site 3} & \multicolumn{2}{|c|}{ Site 4} \\
\hline & Range & Mean & Range & Mean & Range & Mean & Range & Mean \\
\hline $\mathrm{Ni}$ & $20.1-22$ & 21 & $\begin{array}{l}53.9- \\
60.7\end{array}$ & 57.3 & $\begin{array}{l}34.9- \\
36.2\end{array}$ & 35.5 & $\begin{array}{l}14.4- \\
16.2\end{array}$ & 15.3 \\
\hline $\mathrm{Cu}$ & $20.3-25$ & 22.6 & $28-29.8$ & 28.9 & $\begin{array}{l}25- \\
26.5\end{array}$ & 25.75 & $\begin{array}{l}22.7- \\
24.3\end{array}$ & 23.5 \\
\hline $\mathrm{Zn}$ & $32.9-35$ & 33.9 & $46-49$ & 47.5 & $\begin{array}{l}59.2- \\
60.6\end{array}$ & 59.9 & $\begin{array}{l}196- \\
198\end{array}$ & 197 \\
\hline As & $\begin{array}{l}16.6- \\
20.1\end{array}$ & 18.35 & $\begin{array}{l}13.5- \\
14.2\end{array}$ & 13.85 & $\begin{array}{l}22- \\
24.2\end{array}$ & 23.1 & $13-16$ & 14.5 \\
\hline $\mathrm{Ga}$ & $\begin{array}{l}21.6- \\
22.8\end{array}$ & 22.2 & $15-16.3$ & 15.65 & $\begin{array}{l}28- \\
29.3\end{array}$ & 28.6 & $\begin{array}{l}12.3- \\
13.5\end{array}$ & 12.9 \\
\hline $\mathrm{Br}$ & $\begin{array}{l}43.4- \\
48.8\end{array}$ & 46.1 & $\begin{array}{l}11.6- \\
12.8\end{array}$ & 12.2 & $\begin{array}{l}26.8- \\
28\end{array}$ & 27.4 & $\begin{array}{l}71.4- \\
72.6\end{array}$ & 72 \\
\hline $\mathrm{Rb}$ & $\begin{array}{l}10.1- \\
13.6\end{array}$ & 11.8 & $\begin{array}{l}22.3- \\
25.2\end{array}$ & 23.75 & $\begin{array}{l}16.5- \\
17.3\end{array}$ & 16.9 & $\begin{array}{l}5.5- \\
5.9\end{array}$ & 5.7 \\
\hline $\mathrm{Zr}$ & $1.4-2.3$ & 1.85 & $\begin{array}{l}53.9- \\
55.1\end{array}$ & 54.5 & $\begin{array}{l}44.6- \\
45.8\end{array}$ & 45.2 & $\begin{array}{l}1.4- \\
2.2\end{array}$ & 1.8 \\
\hline Mo & $\begin{array}{l}17.4- \\
19.6\end{array}$ & 18.5 & $7.6-8.9$ & 8.25 & $\begin{array}{l}4.1- \\
5.3\end{array}$ & 4.7 & $\begin{array}{l}5.6- \\
6.3\end{array}$ & 5.95 \\
\hline Sn & $3.7-5.8$ & 4.75 & $3.9-4.8$ & 4.35 & $1-2.3$ & 1.65 & $\begin{array}{l}16.9- \\
18.2\end{array}$ & 17.5 \\
\hline $\mathrm{Ta}$ & $115-120$ & 117 & $\begin{array}{l}84.5- \\
89.5\end{array}$ & 87 & $\begin{array}{l}100- \\
105\end{array}$ & 102.5 & $\begin{array}{l}177- \\
182\end{array}$ & 179.5 \\
\hline $\mathrm{W}$ & $\begin{array}{l}19.4- \\
21.9\end{array}$ & 20.65 & $\begin{array}{l}85.8- \\
88.4\end{array}$ & 87.1 & $\begin{array}{l}254- \\
256\end{array}$ & 255 & $\begin{array}{l}88.4- \\
89.5\end{array}$ & 88.9 \\
\hline $\mathrm{Pb}$ & $7-9.5$ & 8.25 & $9.5-10.4$ & 9.95 & $\begin{array}{l}8.6- \\
9.2\end{array}$ & 8.9 & $\begin{array}{l}13.7- \\
14.5\end{array}$ & 14 \\
\hline $\mathrm{Cr}$ & $55-62.5$ & 58.75 & $200-212$ & 206 & $\begin{array}{l}178- \\
183\end{array}$ & 180.5 & $\begin{array}{l}31.6- \\
33.2\end{array}$ & 32.4 \\
\hline
\end{tabular}

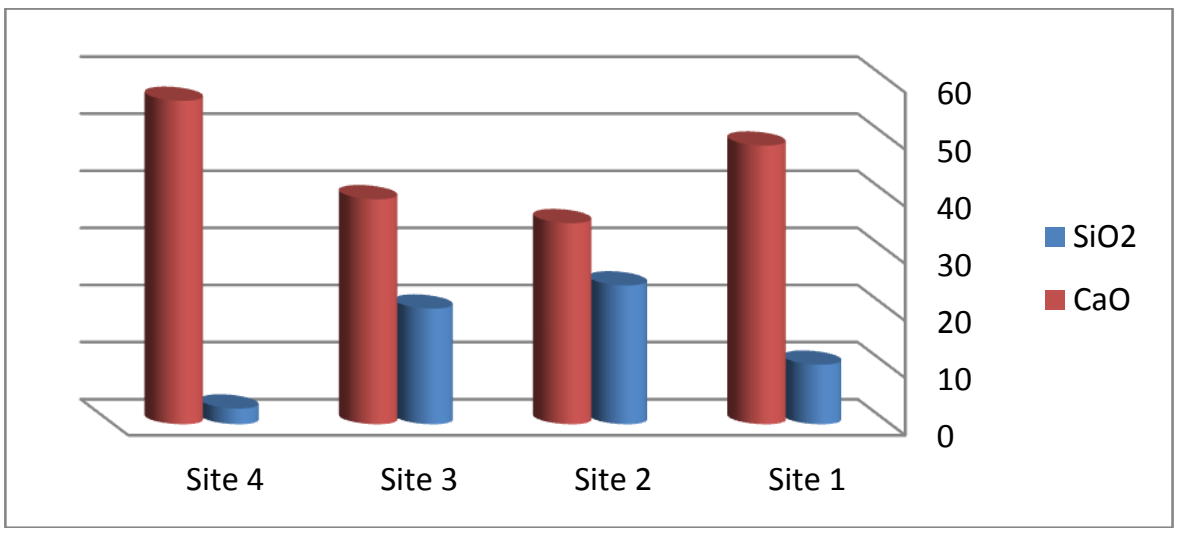

Diagram(5): Distribution of $\mathrm{SiO}_{2}$ and $\mathrm{CaO}$ in the studied sites. 
Mineralogy and Geochemistry of Coral Reef in Iraqi Marine

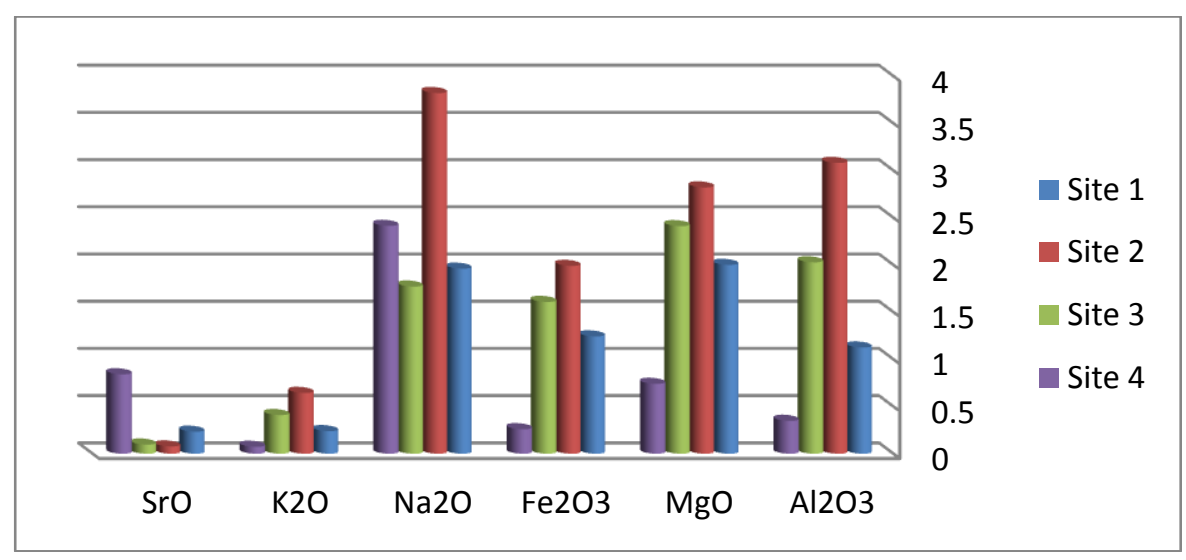

Diagram(6): Distribution of $\mathrm{Al}_{2} \mathrm{O}_{3}, \mathrm{MgO}, \mathrm{Fe}_{2} \mathrm{O}_{3}, \mathrm{Na}_{2} \mathrm{O}, \mathrm{K}_{2} \mathrm{O}$, and $\mathrm{SrO}$ in the studied sites.

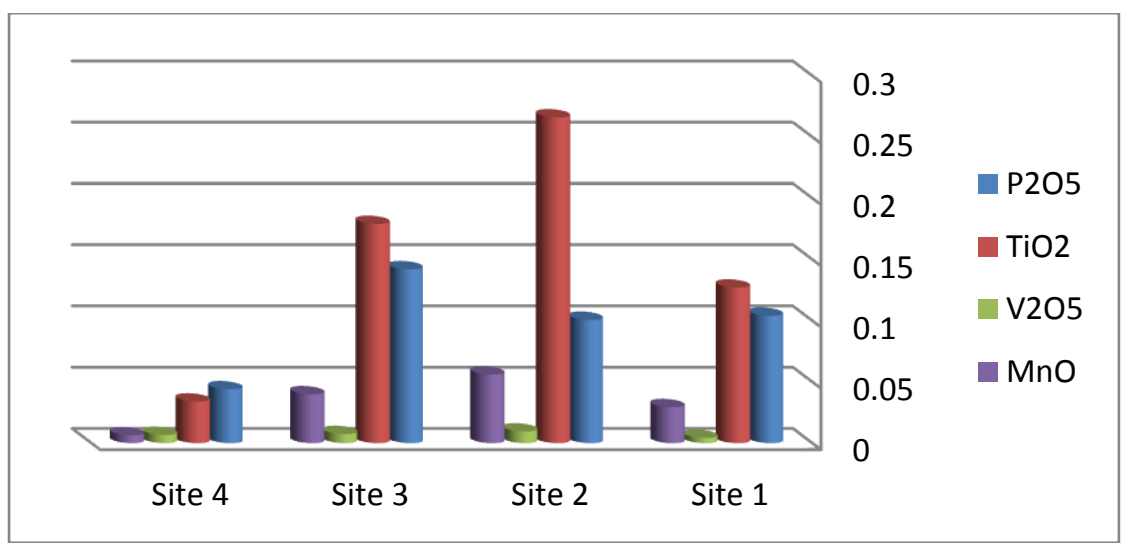

Diagram(7): Distribution of $\mathrm{P}_{2} \mathrm{O}_{5}, \mathrm{TiO}_{2}, \mathrm{~V}_{2} \mathrm{O}_{5}$ and $\mathrm{MnO}$ in the studied sites

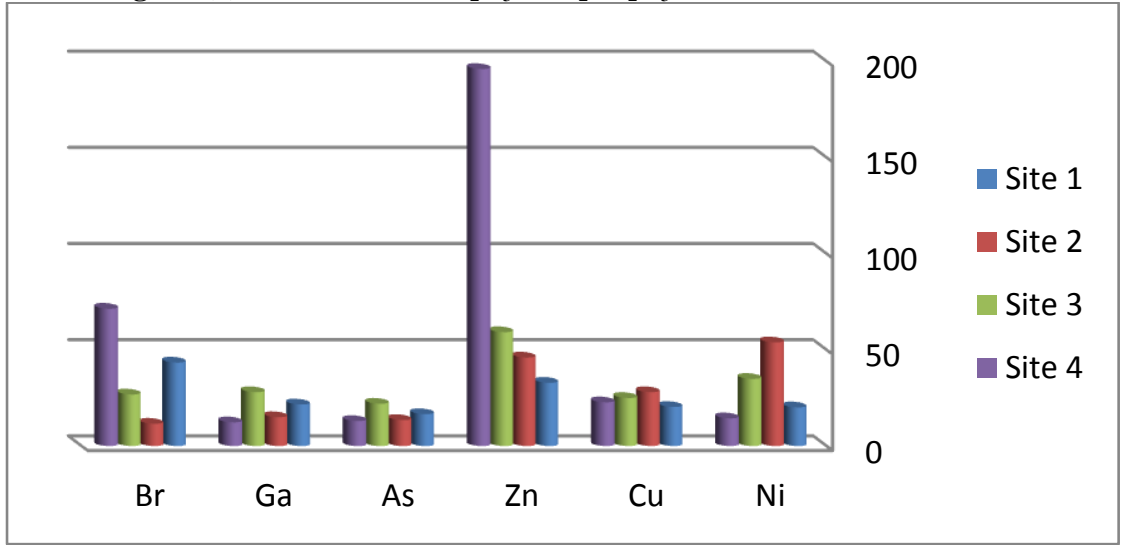

Diagram(8): Distribution of $\mathrm{Br}, \mathrm{Ga}, \mathrm{As}, \mathrm{Zn}, \mathrm{Cu}$, and $\mathrm{Ni}$ in the studied sites. 
Al-Jaberi et al.

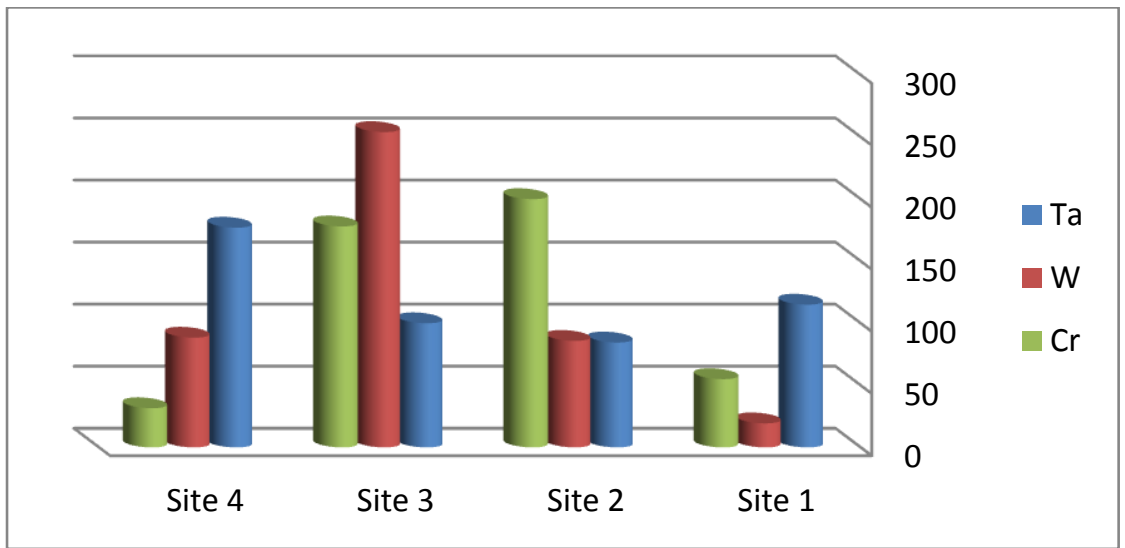

Diagram(9): Distribution of Ta, W, and $\mathrm{Cr}$ in the studied sites.

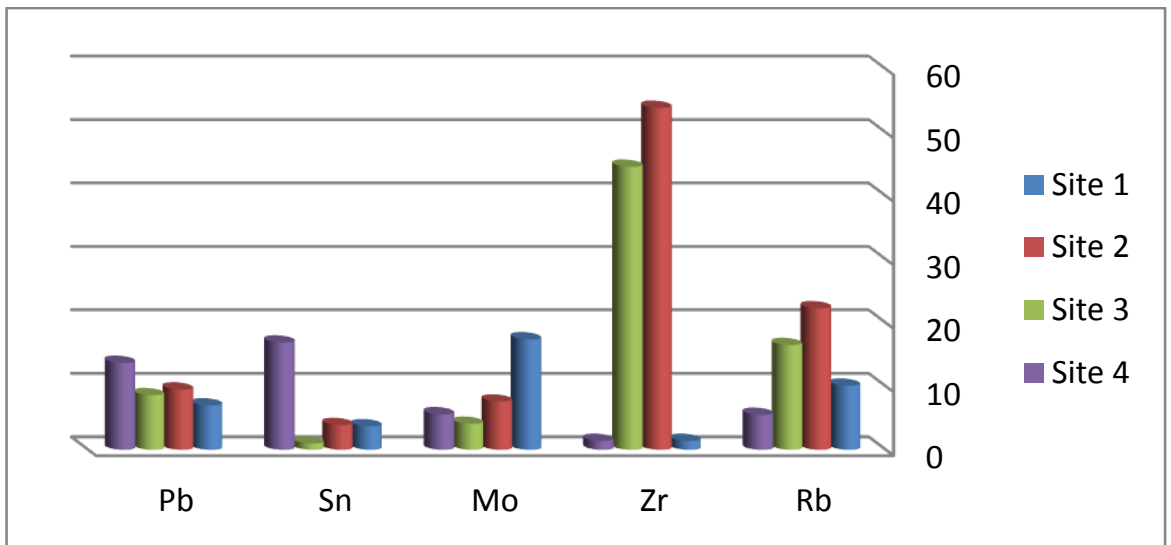

Diagram(10): Distribution of $\mathrm{Pb}, \mathrm{Sn}, \mathrm{Mo}, \mathrm{Zr}$, and $\mathrm{Rb}$ in the studied sites.

\section{CONCLUSIONS}

The present study concluded the following:

1- Aragonite and calcite are the main minerals in the Platygyra pini, the aragonite content at $63.8 \%$ higher than that of calcite at only $28.3 \%$.

2- Calcite, low Mg- calcite, and aragonite are the dominant minerals observed in the Octocoral Menella coral .

3- Quartz and phengite are the main minerals within the sediments of the study area at site 3 , whereas chlorite and talc are most prominent at site 2 .

4- Calcium oxide $(\mathrm{CaO})$ is the most abundant oxide in the study area followed by silica oxide $\left(\mathrm{SiO}_{2}\right)$.

5- Most proportions of calcium oxides in the sediments of coral reef area are providing from coral reefs itself.

6- Most of the silica oxides are obtained from quartz and clay minerals, whereas most calcium oxide observed in the coral reefs. 
7- Some major and trace elements are associated with non-carbonate minerals are increased with decreased of $\mathrm{CaO}$.

8- Strontium and a few trace elements that have radii close to or greater than $1.00 \AA$, have a preferred presence in aragonite layers especially within the $P$. pini. While Mo preferred presence in a calcite layer of Menella.

\section{ACKNOWLEDGMENTS}

We would like to thank the Marine Science Center in Basrah University for cooperation. Special thanks to Sherissa Roopnarain from Cape Town University in South Africa for her assistance.

\section{LITERATURE CITED}

Al-Jaberi, M. H. 2015. Study of the clastic and shells in selected areas at NW of Arabian Gulf- South Iraq. Scolar's Press Publisher - Germany, 249 pp.

Al-Dabbas, M. and Al-Jaberi, M. H. 2015. Elemental distribution in the calcite and aragonite layers of Chione californiensis from the Iraqi Coasts-North Arabian Gulf. Arabian Journal of Geoscience, 8:9433-9440.

Al-Langawi, A. 2013. The Effect of Climate on the Chemical Composition of the Coral Reefs around Kubbar Island-Kuwait. International Journal of Geosciences, 4: 511-528.

Basyoni, M. H. 1999. Sedimentology and Geochemistry of the Karan Island Sediments, Arabian Gulf, Saudi Arabia. J. KAU: Mar. Sci., 10: 89-106. Bathurst, R.G.C., 1975. Carbonate Sediments and Their Diagenesis. Elsevier, Amsterdam, 2nd ed., 658 pp.

Burt, J. 2013. The growth of coral reef science in the Gulf: A historical perspective. Marine Pollution Bulletin Journal,72: 289-301.

Burt, J., Smith, E. G., Warren, C. and Dupont, J. 2015. An assessment of Qatar's coral communities in a regional context. Marine Pollution Bulletin Journal, 105: 473-497.

Calvert, S. E. and Pedersen, T. F. 1993. Geochemistry of Recent Oxic and Anoxic Marine Sediments: Implications for the Geological Record. Marine Geology,113: 67-88. https://doi.org/10.1016/0025-3227(93)90150-T

Chen, S., Guo, X., Yoshino, Y., Jin, Z. and Li, P. 2017. Dehydration of phengite inferred by electrical conductivity measurements: Implication for the high conductivity anomalies relevant to the subduction zones. Geological Society of America Journal, 46(1): 11-14.

Cibin, G., Cinque, G., Marcelli, A., Mottana, A. and Sassi, R. 2008. The octahedral sheet of metamorphic 2M1-phengites: a combined EMPA and AXANES study. American Mineralogist Journal, 93: 414-425.

Coles, S. L. and Riegl, B. M. 2013. Thermal tolerances of reef corals in the Gulf: A review of the potential for increasing coral survival and adaptation to climate change through assisted translocation. Marine Pollution Bulletin Journal, 2(72): 323-332.

Coles, S. and Fadlallah, H. 1991. Reef coral survival and mortality at low temperature in the Arabian Gulf: New specific lower temperature limits. Coral Reefs Journal, 9: 231-237. 
Al-Jaberi et al.

Deer, W. A., Howie, R. A. and Zussman, J. 1992. An Introduction to the Rock-Forming Minerals. 2nd ed., Harlow, England: Longman Scientific \& Technical ; New York, NY Wiley, xvi, 696 pp.

Devnita, R. 2009. Mineralogical characteristics and the pedogenetic processes of soils on coral reefs in Ambon. Geology Journal. Indonesia,4:19-29.

Eghtesadi-Araghi, P. 2011. Coral reefs in the Persian Gulf and Oman Sea: An integrated perspective on some important stressors. Journal f Fisher and Aquatic Science, 6(1): $48-56$.

Falter, J. L. Atkinson, M. J. and Langdon, C. 2001. Production-respiration relationships at different timescales the Biosphere 2 coral reef biome. Limnol Oceanogr Journal, 46: 1653-1660.

Feely, R. A., Sabine, C., Lee, K., Berelson, W., Kleypas, J., Fabry, V. J. and Millero, F. J. 2004. Impact of anthropogenic $\mathrm{CO}_{2}$ on the $\mathrm{CaCO}_{3}$ system in oceans. Journal of Science, 305: 363-366.

Khan, N., Albadran, A. A. and Albadran, B. 1992. Some Engineering aspects of the alluvial deposits at Basrah region, S. Iraq. Geology Journal, 25(1):80-91.

Kleypas, J., McManus, J., Lambert, A. and Menezt, B. 1999. Environmental Limits to Coral Reef Development: Where Do We Drawthe Line?. Journal of American Zoology, 39: 146-159.

Lambeck K. 1996. Shoreline reconstructions for the Persian Gulf since the last glacial maximum. Journal of Earth Planet Science, 1-2 (142): 43-57.

Langdon, C., Takahashi, T., Sweeney, C., Chipman, D. W., Goddard, J. G., Marubini, F., Aceves, H., Barnett, H. and Atkinson, M. 2000. Effect of calcium carbonate saturation state on the calcification rate of an experimental coral reef. Journal of Global Biogeochemical Cycles, 14(4): 639-354.

Liu, Q., Jin, Z. and Zhang, J. 2009. An experimental study of dehydration melting of phengite-bearing eclogite at 1.5-3.0 GPa. Journal of Science Bulletin (China), 54: 2090-2100.

Machado, F. B. 2016. UNESP Universidade Estadual Paulista. Recovered in: <http://www.rc.unesp.br/museudpm/banco/silicatos/filossilicatos/talco.html>. (Accessed at: 17/07/2016)

Mookherjee, M. and Redfern, S. A. T. 2002. A high-pressure Fourier-transform infrared study of the interlayer and Si-O stretching in phengite-2M 1. Journal of Clay Minerals, 37: 323-336.

Perkol - Fenkel, S. and Banayahu, Y. 2007. Defrential recruitment of benthic communities on neighboring artificial and natural reefs. Journal of Experimental Marine Biology and Ecology Journal, 340: 25-39. 


\section{Mineralogy and Geochemistry of Coral Reef in Iraqi Marine}

Pilcher, N. J., Wilson, S., Alhazeem. H. and Shokri. M. 2000. Status of Coral Reefs in the Arabian/Persian Gulf and Arabian Sea Region (Middle East). In: Wilkinson, C. (ed.): Status of Coral Reefs of the World: Australian Institute of Marine Science, Australia. 64 PP.

Pohl, T., Al-Muqdadi, S., Ali, M., Al-Mudaffar, N., Ehrlich, H. and Merkel, B. 2014 Discovery of a living coral reef in the coastal waters of Iraq. Scientific Report, 4: 4250 .

Pontes, I. F. and Almeida, S. 2005. Talco. Rochas \& Minerais Industriais - Usose especificações. CETEM, 628 pp.

Rezai, H. and Savari, A. 2004. Observation of reef fishes in the coastal waters off some Iranian Islands in the Persian Gulf. Journal of Zoology in the Middle East, 43 (2): 488-499.

Riegl, B. 2002. Effects of the 1996 and 1998 positive sea-surface temperature anomalies on corals, coral diseases and fish in the Arabian Gulf (Dubai, UAE). Journal of Marine Biology, 140: 29-40.

Schmidt, M. W. and Poli, S. 2014. Devolatilization during subduction. In R.L. Rudnick, Ed., Treatise on Geochemistry: The Crust, 2nd ed., Elsevier, Amsterdam. 3, pp 669-701.

Schroeder, J. H. and Purser, B. H. 1986. Reef Diagenesis Introduction. In: Schroeder, J. H. and Purser, B. H. (eds), Reef Diagenesis. Springer - Verlag. New York, pp 1-7.

Smith, E. G., Hume, B. C., Delaney, P., Wiedenmann, J. and Burt, J. A. 2017. Genetic structure of coral-Symbiodinium symbioses on the world's warmest reefs. PLOS ONE 12:e0180169. doi: 10.1371/journal.pone.0180169

Tucker, M. E. and Hollingworth, T. J. 1986. The Upper Permian Reefs Complex (EZ1) of North East England : Diagenesis in Marine Evaporating Setting. In: Schroeder, J. H. and Purser, B. H. (eds), Reef Diagenesis. Springer - Verlag. New York, pp 270-290. 
Bull. Iraq nat. Hist. Mus.

December, (2018) 15 (2): 189-206

$$
\begin{aligned}
& \text { معدنية و جيوكيميائية الثعاب المرجانية في البيئة البحرية العر اقية في الجزء الثمالي من } \\
& \text { الخليج العربي الني } \\
& \text { مهند حامد الجابري **** ، معتز عبد الستار الدباس***، ابا ذر جبار بشار } \\
& \text { و مناف قاسم جابر }
\end{aligned}
$$

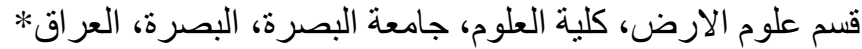

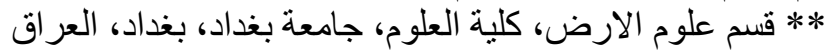

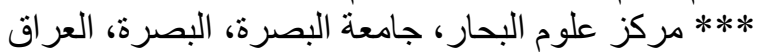

\section{الخلاصة}

تم دراسة معدنية وكيميائية منطقة الشعاب المرجانية في شمال غرب الخليج العربي

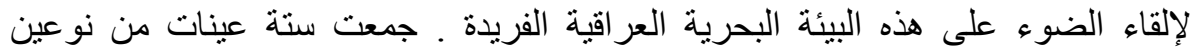
رئيسين من الثعاب المرجانية و Platygyra pini و في موقعين. في حين تم اختيار ثمانية عينات من الرواسب البحرية المحيطة من موقعين آخرين. حددت المعادن عن موعن طريق الأشعة السينية الحائدة

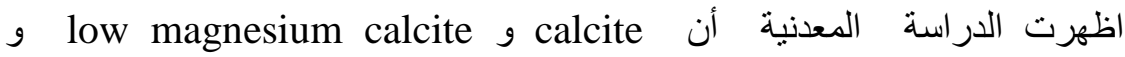
، هي المعادن الرئيسية التي تتألف في Octocoral Menella في الموقع 1 aragonite

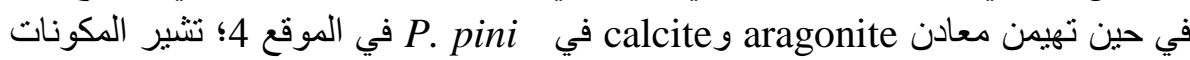
الغير الكربونايتية إلى أن هذه الثعاب المرجانية تحتوي على نسب من ون و

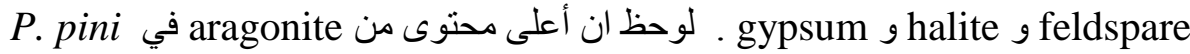

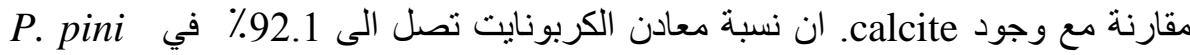

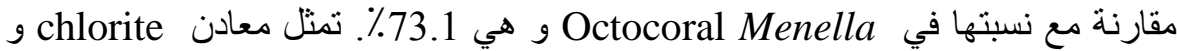

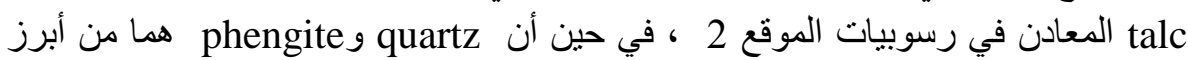
المعادن في رسوبيات الموقع 3.

ان معدن ال phengite هو أول اكتشاف في رواسب الخليج العربي ، في حين أن talc هو أول اكتثاف في الرواسب البحرية العر اقية. 
Mineralogy and Geochemistry of Coral Reef in Iraqi Marine

ان تركيز CaO هو الأكثر وفرة في جميع العينات التي تم تحليلها في منطقة الثعاب المرجانية يليها SiO2؛ هناك أعلى نسب من CaO في

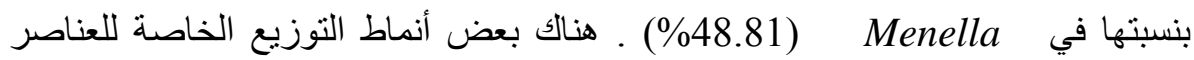

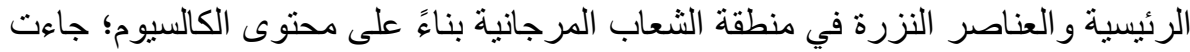

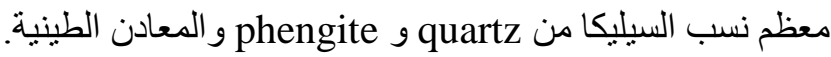

لوحظ هناك تو اجد نسب عالية من تراكيز Al2O3 و

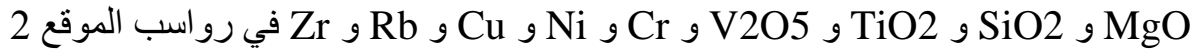
مقارنة بالمواقع الأخرى؛ يمكن أن تعزى هذه النتائج الى ارتباط هذه العناصر بالمعادن

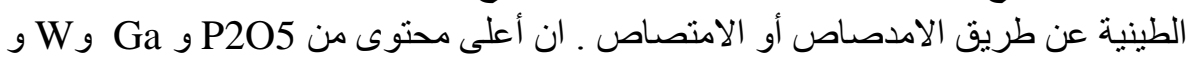

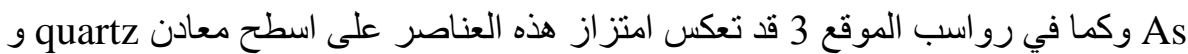

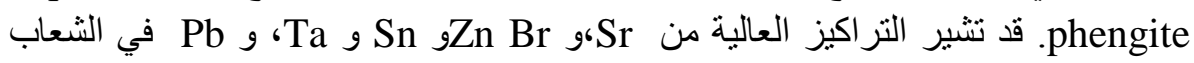
المرجانية Platygyra pini إلى التأثير ات النسبية للتغير البيئي داخل المنطقة المدروسة. 